\title{
ADVERBIAL INTENSIFIERS IN CONTEMPORARY POLISH AND SLOVAK
}

\author{
SYLWIA SOJDA \\ Institute of Slavic Languages, University of Silesia in Katowice, Poland
}

\begin{abstract}
SOJDA, Sylwia: Adverbial intensifiers in contemporary Polish and Slovak. Jazykovedný časopis (Journal of Linguistics), 2019, Vol. 70, No 1, pp. 55 - 72.
\end{abstract}

\begin{abstract}
The paper discusses the intensifying functions of some lexical units derived from adverbs in a cross-linguistic Polish-Slovak perspective. The expression of intensification in Polish and Slovak has not been widely explored, which is why the present paper aims to point out a few aspects of this phenomenon in two closely related Slavic languages, which may contribute to help fill this gap. Intensification is without doubt a very interesting, pervasive and complex phenomenon in linguistics and is understood here as the process of quantitative change of a feature, activity or state. That change refers to the increase and decrease in intensity of a feature/ activity/state according to an approved canon. The components of the category of intensification are therefore both, intensifying and deintensifying. Therefore, it is also postulated that a class of intensifiers/deintensifiers should be distinguished as means of intensification/deintensification. Intensifiers have also been a long fruitful topic of investigation in sociolinguistic research: on one hand intensification systems are unstable and tend to change rapidly in any speech community and on the other, the use of intensifiers tends to vary across demographic categories, especially age and gender. Intensification can also be researched due to 'delexicalization', which is defined as the reduction of the independent lexical contents of a word, or group of words, so that it comes to fulfil a particular function - the original meaning of the word is gradually lost as it evolves into a marker of intensification. The paper aims also to show that the more delexicalized an intensifier becomes, the more it will lose its lexical restrictions and increase in frequency. Through frequency of use and over time, intensifiers tend to lose their intensifying force and the renewal process occurs. This process promotes other adverbs, be they newly created adverbs or already existing ones, to the rank of intensifiers - it seems that the class of intensifiers may be an open class. The undertaken analysis has shown that there are a number of aspects which can be considered while describing intensifiers.
\end{abstract}

Key words: category of intensification, adverbs, intensifiers, delexicalization

„Ako môže byt' niečo diabolsky dobré? však to je úplný paradox, nie?
Celkovo, niektorí l'udia majú asi moc obmedzenú slovnú zásobu ,"

(Omnia Slovaca Publica II)

\section{INTRODUCTION ${ }^{1}$}

The above quote points to a paradox whereby something coming from the Devil, associated in our culture with evil, can be good, and someone competent in

${ }^{1}$ I would like to thank two anonymous reviewers for constructive criticism and helpful suggestions. 
using the lexical unit diabolsky dobré in a proper context might have limited lexical resources. Reflections on this intensification will be used here as an attempt to resolve the paradox highlighted above.

Intensification is without doubt a very interesting, pervasive and complex phenomenon in linguistics. It should definitely be investigated from general and comparative points of view to highlight its status as an autonomous category in the realm of modification. Research on adjective intensifiers in English has been a topic of linguistic studies since Cornelis Stoffel's Intensives and Down-toners: A study in English adverbs, published in 1901 (Stoffel, 1901). The concept of the category of intensification was disseminated by Dwight Bolinger's Degree words (Bolinger, 1972 ) and since then, various aspects of this phenomenon have been explored. ${ }^{2}$

Besides receiving large consideration in the domain of semantics and pragmatics, intensifiers have also been a long fruitful topic of investigation in sociolinguistic research. Authors engaged in this research observed that, firstly, intensification systems are unstable and tend to change rapidly in any speech community and secondly, the use of intensifiers tends to vary across demographic categories, especially age and gender (Beltrama, 2015, p. 17).

As far as lexicology and semantics were concerned, the researchers' attention was focused on the issue of scaling, gradation and comparison. These observations refer to various European languages, with the accompanying varying intensity and frequency of linguistic research. The expression of intensification in Polish and Slovak has not been widely explored, which is why the present paper aims to point out a few aspects of this phenomenon in two closely related Slavic languages, which may contribute to help fill this gap. The problems undertaken here will be concentrated around the process of delexicalization, because due to this, some adverbials appear as intensifiers.

\section{DEFINING INTENSIFICATION AND INTENSIFIERS}

In this part the theory and background of intensification and intensifiers is presented to give a framework for the study. The content of the term intensification is defined in terms of the semantic features assigned to the lexical units. Furthermore, some categories and gradable expressions may often be intensified. Thus, intensification is strictly connected with lexis, semantics and pragmatics and many researchers point different approaches to this phenomenon. It is also a lexico-grammatical category that is mainly employed to achieve expressivity (Lorenz, 2002, p. 143).

Randolph Quirk et al. claim that "the intensifier subjuncts are broadly concerned with the semantic category of degree" (1985, p. 589), which has been confirmed by other linguists, i.e. Polish linguist Jadwiga Puzynina, who notes that

\footnotetext{
${ }^{2}$ See the list of references established by Lucile Bordet (2017b) which includes works often cited in intensification studies. That list is not exhaustive and contains works, mostly in English and French, but also in other languages (German, Portuguese and Modern Greek) published by 2017.
} 
this category contains features, states, processes and activities and should be treated as one of the subcategories of gradation (Puzynina, 2001, p. 321). Moreover, this term "does not refer only to means whereby an increase in intensification is expressed. Rather, an intensifying subjunct indicates a point on an abstractly conceived intensity scale; and the point indicated may be relatively low or relatively high" (Quirk et al., 1985, p. 589). J. Puzynina claims the same - the phenomenon of intensification involves not only an increase of the intensity of features, states, processes, activities, but it also includes the opposite - a reduction of the intensity of a given feature, activity, or state. A similar opinion is presented by other researchers, for instance, Ireneusz Jakubczak, who identifies intensification with scaling a quality (expressed by an adjective) up or down a semantic scale (Jakubczak, 1985, p. 63). On the contrary, there is an approach (Beltrama, 2015, p. 17) which indicates at least two different modes of meaning composition for intensifiers: a lexical one, where intensifiers boost the scales encoded by a gradable predicate and a non-lexical one, in which intensification operates over a scale that is introduced via pragmatic reasoning or by shifting the focus on the speaker's commitment towards the sentence.

As far as the present research is concerned, intensification is understood here as the process of quantitative change of a feature, activity or state. That change refers to the increase and decrease in intensity of a feature/activity/state according to an approved canon. The components of the category of intensification are therefore both intensifying and deintensifying. This approach has caught on in recent years among scholars as there have been a number of studies of intensifiers and their characteristics. Barbara Mitrenga, while describing the indicators of intensity (both of high and low degree), uses the terms intensifier ('intensyfikator') and deintensifier ('dezintensyfikator'), defining them as lexical units, including adverbs (Mitrenga, 2016). Therefore, it is also postulated that a class of intensifiers/deintensifiers should be distinguished as means of intensification/deintensification.

The term intensifier has been used in various ways in linguistic studies. The most common definitions identify intensifiers with adverbs (belonging to the subcategory of adverbs of manner (Bordet, 2017a); intensifiers are also called adverbs of degree, intensive adverbs, degree modifiers or degree words and are forms that add "a degree measure onto its referent" (Reicheld - Duhan, 2014, p. 63; Tagliamonte, 2012, p. 320). Similarly, Juraj Šikra equates intensifiers with adverbs of degree which could partially be treated as intensifiers as the degree and intensiveness semantically significantly correspond. On the other hand, he assumes that adverbs of a bigger degree (i.e. náramne, tuho, dotuha, výrazne, významne, význačne, urputne, mocne, výdatne, prílišne, citel’ne, neúmerne, netušene, nevýslovne, neúrekom - which can be replaced by vel'mi) often act as intensifiers (Šikra, 1991, pp. 98, 101).

The change in the status of a lexical unit occurs by way of its change at a sentence level. One of the first signs of the ongoing process of changing the 
meaning of such a unit is the position next to the adjective. A typical adverb combines with a verb, while the typical position for an intensifier is before a given adjective (or the appropriate adjectival adverb). The intensifier can also come into relation with a verb (or participle), but only with these verbs that offer the possibility for intensifying - apart from the activity itself or the state in their meaning, there is also a gradable element, evaluating this activity or state (Bałabaniak, 2014, p. 29). The Polish and Slovak lexical material shows that it is the position other than next to the verb which often foreshadows the unit's readiness to change its class or to create a new unit - i.e. an intensifier. The occurrence of a unit in the mentioned positions and with a given type of adjective (being gradable) leads us to assume that the word may potentially become an intensifier. Nonetheless, the development of a new unit does not always take place - the formation of an intensifier means that there are usually two lexical units of the same form: intensifier and adverb. One of statements considered in this study is that intensifiers are derived mainly from adverbs and their significance is related to the high intensity of a feature. The "sharpness" of this feature contributes to the fact that the word is also used in the intensifying meaning to convey the scale of the phenomenon perceived by the sender (which may also be the speaker's emotions). The negative meaning is usually perceived as more "visible" because the phenomenon it concerns is more intensely felt, so some negative adverbs may be a source of intensifiers as well (Bałabaniak, 2014, p. 30).

Numerous studies have contributed to the structural description and semantic categorization of intensifiers. As Irina Lebedeva and Lena Pavlova have noticed (2016), scholars have put forth a diversity of approaches - identifying intensifiers with adverbs is not the only methodological solution. As early as 1967, Henryk Misz provided a description of the syntactic groups of written Polish, among which he distinguished classes of syntactemes (words with syntactic value and a determinative function), with intensifiers as one of the classes (Misz, 1967, p. 55). This class includes syntactemes calkiem, zupetnie, dosyć, bardzo, nader, nadzwyczaj, niezmiernie, za, zbyt, zanadto, prawie, niemal, trochę, coraz, lekko, mocno, etc. They function as subordinators to adjectives and adverbs (in an equal or higher degree), and some also accompany nouns and verbs.

As already mentioned, there are several characteristics of intensifiers which differentiate them from adverbs, even though the conceiving of lexical intensifiers based on adverbs has been known for a long time. As Lucile Bordet (2017a) claims, intensifiers are popular because of their intensifying force.

\subsection{Intensifiers and grammaticalization}

Grammaticalization is defined as "that subset of linguistic changes whereby a lexical item or construction in certain uses takes on grammatical characteristics, or through which a grammatical item becomes more grammatical" (Hopper - Traugott, 2003 , p. 2). This is a larger and continuous process consisting of several stages. As 
Christian Lehmann points out, lexicalization and grammaticalization are processes that have much in common $(2002$, p. 1). The more grammaticalized an intensifier, the more it will lose its lexical restrictions and increase in frequency. At the same time, its collocates and contexts of occurrence will change in relation to its own semantic change (Lorenz, 2002, p. 144)

In the theoretical works, intensifiers could be described either as an example of lexicalization or delexicalization - this is mostly a matter of the definition of these processes. Here, I present both approaches, but I also emphasize that in this study I favor the latter.

One of the approaches, introducing lexicalization, distinguishes the transition of lexical units from the adverbial class (units initially used as adverbs of manner) to the class of intensifiers as a long-lasting process. First, the distribution of the adverb is gradually expanded - initially in relation to situations and events in which the secondary meaning could be metaphorical. The word does not lose its original meaning, but it begins to function in contexts in which a typical adverb does not normally occur. Increasing connectivity "blurs" the meaning of the adverb. The word undergoes gradual lexicalization and its semantic relationship with its basis starts blurring. Consequently, a new indivisible unit (intensifier) with a new meaning and wider distribution than the original adverb is formed. It should be noted, though, that not all intensifiers are lexicalized to the same extent (in certain cases, the process of forming an intensifier is complete, whilst in other cases, it is still ongoing or is only starting to take place), and not all of them can function in analogous contexts (Mitrenga, 2016, pp. 228 - 229). A case in point is the Polish unit strasznie, which functions both as an adverb meaning 'incredibly, frighteningly, scarily' and as an intensifier meaning bardzo 'very much'. Stanisław Koziara (2003, p. 348) points out that nowadays this lexicalized meaning increasingly prevails over the meaning 'frighteningly, scarily' which is still recorded in dictionaries as the primary one. The Polish adverbs daleko, dużo, wiele, wysoko, mato and the Slovak adverbials d'aleko, vel'a, vysoko, málo, based on the parametric adjectives Pl. daleki, duży, wielki, wysoki, mały, Sk. d'aleký, vel'ký, vysoký, malý; or others, derived from adjectives semantically referring to the concept of fear, ugliness, supernatural forces, evil

${ }^{3}$ Bardzo 'very' is the most representative example of an intensifier, which does not carry content, but only the intensity of the feature or state: "connected with a verb marks a high degree of activity or state, and combined with an adjective or an adverb strengthens the characteristic expressed by them. The effect of the severity of the trait can also be obtained by joining the adjective and adverb with bardzo 'very much', which, however, does not enter the syntactic bunch with the adjective in a different degree than equal" (Węgiel, 1995, p. 108); it can be seen that the extent of the occurrence of lexeme bardzo used to be much wider than it is today, namely, the lexeme could also appear in the neighbourhood of adjectives and adverbs of a higher degree, e.g. bardzo lepszy, bardzo znaczniejsze, bardzo stabsze, bardzo tatwiej, bardzo lepiej. In contemporary Polish, these types of constructions are not acceptable, a quantitative intensifier may replace bardzo, e.g. bardzo, niewiele or a qualitative one, e.g. znacznie. An intensifier may not occur at all, as the intensifying meaning lies in comparative degree (Jakubowicz, 2014, p. 67). 
spirits: Pl. straszny, przeraźliwy, potworny, odrażajacy, diabelski, szatański, Sk. strašný, hrozný, ohavný, prišerný, diabolský, satanský, can function in the language as lexical intensifiers, Pl. strasznie, przeraźliwie, potwornie, odrażajaco, niesamowicie, diabelnie, diabelsko, szatańsko, Sk. strašne, hrozne, ohavne, príšerne, diabolsky, satansky, which is the result of a change in meaning.

According to the fact that intensifiers are considered to be lexicalized, it is evident that one of the criteria for recognizing a lexical unit as an intensifier is the degree of its lexicalization. Moreover, some researchers point out that only a fully lexicalized unit can be considered an intensifier.

On the contrary, many scholars use the term 'delexicalization' due to intensification. Delexicalization is defined as "the reduction of the independent lexical contents of a word, or group of words, so that it comes to fulfill a particular function" (Tagliamonte, 2008, p. 363; Partington, 1993, p. 183) - the original meaning of the word is gradually lost as it evolves into a marker of intensification. Delexicalization does not just happen abruptly by chance, overnight, but occurs in a step-by-step fashion: the first step includes metonymic or metaphoric extension from the original meaning, followed by the intensifier being used with a restricted set of adjectives or adverbs. In the next stage it is used more frequently for emphasis and intensification and concomitantly with a wider and wider set of adjectives of different types. The more delexicalized an intensifier becomes, "the more it will lose its lexical restrictions and increase in frequency" (Lorenz, 2002, p. 144). To sum up: here the investigated units have the ability to take over from negative or positive adjectives which indicates that they are delexicalized ones.

Recent studies (Lorenz, 2002; Bordet, 2017a) have focused on the constant change (renewal) and recycling of intensifiers during the last few decades. Renewal takes place when "existing meanings may take on new forms" (Hopper - Traugott, 2003, p. 122). This is generally characterized by coming up with new ways of saying roughly the same things which avoids repetition.

\subsection{Intensifiers and subjectivity}

The means of intensification occur in contexts that are considered intensifying. The context of intensification and its subjectivity are clearly marked. If we consider the result of a comparison to be intense, where the compared object exhibits a given feature to an extent different from the standard specified by the language, and we consider the notion of a feature in the speaker's mind as the standard language (Bałabaniak, 2013, p. 77), then the observation of the Greek researcher Angelika Athanasiadou seems justified. She claims that " $<$ intensification $>$ is a concept that refers not only to the expression but also to [the] achieving of subjectivity, in that the conceptualizers are very much involved in projecting their own perspective on an entity" (Athanasidou, 2007, p. 555). This is a multidimensional phenomenon; the intensification of the expression depends on the speaker's perspective, point of view 
and attitude. Therefore, what some regard as intensification, an attempt to intensify expression and put a particular spin on content, others hold to be merely a simple description of the surrounding world. Although intensification is not unequivocal and is understood differently by individual people, it makes statements expressive, stronger in reception, sometimes blunter or marked, e.g. emotionally. Intensifiers are often used in expressive, emotional sentences. They have a stronger emotional and/ or connotative function than mere comparison/grading (Batinić - Kresić - Pavić Pintarić, 2015, p. 8). Moreover, the intensity is vivid. It creates new images in the mind of the reader, directs him to a certain way of receiving thoughts, and influences his imagination. It makes the content more interesting and open to interpretation.

\section{INTENSIFIERS CONNECTED WITH FEAR}

The discussion to follow focuses on three Polish intensifiers and their counterparts in Slovak: potwornie/príšerne, piekielnie/pekelne and diabelsko (diabelnie)/diabolsky. These examples were not picked at random; they were chosen specifically because of their provenience: each is transparently related to inhuman power-source words derived from adjectives associated with something horrendous, with fear and evil. The paper aims to show their distribution and possible collocations while functioning as intensifiers in contemporary Polish and Slovak.

In their lexical use, they operate as boosters, which "denote a high degree, a high point on the scale" (Quirk et al., 1985, p. 590) and belong to amplifiers, which along with downtoners are, according to Quirk et al., subsets of intensifiers. Amplifiers scale upward from an assumed norm: maximizers reach the extreme point on the scale, while boosters convey the high degree without reaching the extreme end of the scale. Another approach, established by Carita Paradis (1993, p. 27) relates intensifiers to degree modifiers called reinforcers. Degree modifiers fall into two subsets: one involves grading in terms of totality (totality modifiers maximizers), the second involves scaling (scalar modifiers - boosters). Similarly, in Slovak linguistics - Lubomír Kralčák within reinforcing (Sk. zosilnenie, koroborácia) distinguishes maximizers (Sk. maximilizátory), magnifiers (Sk. magnifikátory) and majorizers (Sk. majorizátory) (Kralčák, 1992, p. 22). The group of magnifiers covers such modifiers as discussed here potwornie/prišerne, piekielnie/ pekelne, diabelnie/diabolsky, but while describing them in this study, I use the term boosters. Another important characteristic of boosters is that they "form open classes, and new expressions are frequently created to replace older ones whose impact follows the trend of hyperbole in rapidly growing ineffectual" (Quirk et al., 1985 , p. 590).

The occurrence of different types of degree modifiers is ultimately conditioned by gradable features in the adjective: not all gradable adjectives can be combined with all intensifiers. For scalar adjectives it is natural to select intensifiers which are 
capable of indicating a subrange of the scale. As far as the boosters analysed in this paper are concerned, they commonly modify gradable words - and usually collocate with scalar adjectives, as in the examples bellow ${ }^{4}$ :

(1) Jest to czlowiek piekielnie odwazny i diablo sprytny.

(2) Czeka nas potwornie ciężka praca.

(3) Woda w basenie byla zielona i potwornie brudna.

(4) „Martel” diabelsko dobry koniak.

(5) Mogę powiedzieć, że to jest diabelnie stare.

(6) Tá príšerne bystrá mladá žena.

(7) A stalo sa to najhoršie, čo sa mohlo stat' - kobyla mala hned' po štarte kolíziu, zaostala a potom v pekelne rýchlom tempe nestačila dohnat' stratu.

(8) Úrokové finančníctvo neprodukuje nič dobré, čo by nemohlo vyprodukovat' bezúrokové finančnictvo. Zato ale produkuje niečo diabolsky zlé a škodlivé, čo bezúrokové finančnictvo neprodukuje!

(9) Pekný, ušlachtilý, žiarivý. A diabolsky atraktivny. Áno, žiarivý a pekný, hovorili podaktorí.

The statement often undertaken in research is that amplifiers' (maximizers' and boosters') collocations are likely to be limited in different ways, though boosters have a broader collocation range than do maximizers (Recski, 2007, p. 227). Various scholars (e. g. Paradis, 2000; Partington 1993) state that different characteristics should be attributed to intensifiers based on their positive and negative scaling and degree of boundedness, which indicates to which extent they collocate with a particular type of adjective. The more words an intensifier collocates with, the more delexicalised it is. New intensifiers are expected to have fewer collocates, whereas older ones are used with a wide array of adjectives. As an example, let us look at the intensifier terribly which apart from, still retaining the meaning of 'terror', has gradually acquired a more grammatical meaning with a more neutral intensifying function.

\section{1. potwornie/prišserne}

The Polish adverb potwornie is synonymous to koszmarnie, okropnie, straszliwie, strasznie and is derived from the adjective potworny, primarily connected with monsters, something ugly, horrid, means 'budzący przerażenie', 'bardzo brzydki'. In $S D o r^{5}$ there are two possible meanings: 1. 'bardzo brzydko, odrażająco, przerażająco, strasznie' (Obaj wygladamy potwornie) and 2. 'w dużym stopniu, bardzo, ogromnie, niezmiernie' (byto potwornie goraco; potwornie gruby pień). SJP

${ }^{4}$ Slovak examples were taken from Slovak language corpora ARANEA: OMNIA SLOVACA PUBLICA II (unesco.uniba.sk, aranea.juls.savba.sk); Polish exemplifications from Polish language corpora NKJP (www.nkjp.pl).

${ }^{5}$ The abbreviations of the dictionaries will be expanded in the list of literature at the end of the paper. 
$P W N$ equates potwornie with strasznie and the newest on-line dictionary ${ }^{6}$ indicates the negative collocation of potwornie: ' $\mathrm{w}$ tak znacznym stopniu, że mówiący ocenia to negatywnie':

(10) Wszyscy prosili ja do tańca, a ja bytem potwornie zazdrosny.

(11) Na dodatek była potwornie wściekła, że wyrwałem się z domu podczas jej nieobecności.

(12) Ale moim dzieciom, które zaczynaja kariery, jest potwornie trudno.

As can be noticed, the adjectival adverb potwornie has extended its meaning and nowadays functions with the intensifying implication of 'very', 'huge', 'prevailing', i.e. (13) - (15):

(13) Olbrzymi jak wilk. I potwornie serdeczny. Dusza nie pies!

(14) Nawiasem mówiąc, niektóre byly potwornie dlugie, ich czytanie trwało po czterdzieści pięć minut, co byto potworna tortura dla stuchaczy, a uktady niedzielnych mszy w miastach sa przecież takie, że co godzinę zaczyna się nowe nabożeństwo, więc czytanie takich kobyt potwornie dezorganizowato cata prace.

(15) Ma to być również sposób na ożywienie gospodarcze potwornie biednego regionu.

Analogically, the Slovak lexeme príserne is in the SSJ recorded as an adverb derived from the adjective prišserný, originally meant 'súvisiaci s prítmím', 'skrývajúci sa v prítmí' > strašidelný, strašný (SESS, 2015, p. 475). The dictionary gives two meanings of príšerný: 1. 'vzbudzujúci hrôzu, strach, hrozný, strašný, obludný': príšerné sny; 2. (colloquial and expressive) which clearly points to the intensifying element 'vel'mi vel'ký, ohromný, nesmierny': prišerný strach, príšerná bolest'. According to adverbial usage, prišserne means 1. 'strašidelne, strašne, desne, hrozne' and 2. (colloquial and expressive) 'vel'mi, náramne, ohromne, nesmierne, strašne, hrozne'. The latter is confirmed by the contexts recorded in the Slovak language corpora: príšerne bystrá - vel'mi bystrá, príšerne nazlostená - vel’mi nazlostená, príšerne vysoké - vel'mi vysoké, prišerne drahý - vel'mi drahý and exampled in (16) - (19):

(16) Á, bezpochyby slečna Harringtonová. Tá prišerne bystrá mladá žena.

(17) Teraz je Violet na Dereka príserne nazlostená, tak myslim, že o ich prekáračky nebude núdza (...).

(18) Fashion bloggerská uniforma: prǐserne vysoké topánky, leginy s nejakými galaxiami alebo podobne (...).

(19) Londýn je príšerne drahé mesto a robila som si tam radost’ malými vecami.

${ }^{6}$ Online dictionary of Polish language, available at: https://www.wsjp.pl. 
Príšerne can also function as an adverb next to the verb, as in (20) - (27):

(20) Ak sa vás kamarátka pred vašou ratolest'ou spýta, či jej pristane nová blond farba, nemusite hned' povedat', že vyzerá príšerne.

(21) Ak tím hrá tak príšerne, ako dnes hrali, tak tréner musí stát' na hranici priestoru, ktorý majú tréneri vyhradený, a musí poriadne usmerňovat' Hron.

(22) Varovný prst zdvihli aj noviny The Independent: Toto pretrvanie ponúklo dost' nestability. Anglicko odolalo, hoci večer obsiahol hrozbu, že to dopadne príšerne.

(23) (...) aj ja som ho vel’mi l’utovala, pretože Šeherezáda sa voči nemu chová príšerne a najmä pred Enginom.

(24) Príšerne ma bolelo celé telo, až som mala pocit, že sa vôbec nepostavím na nohy.

(25) Pre toto sa pred mamou príserne hanbi!!

(26) Zubná nit'-najlepši priatel' zubov. Aj vy ste sa stretli s tvrdením, že pokazené zuby príšerne smrdia?

(27) To platí aj u mňa - otec sa potí tiež príšerne. Je však astmatik, a tak sa domnievam, že aj kvôli tomu.

What is worth saying at this point is, that in (20) - (23) príšerne is an adverb synonymous to strašne, while in (24) - (27) it functions as an intensifier synonymous to vel'mi. This confirms that in some statements the same lexeme can function or as intensifier or an adverb. Moreover, the adverb seems to take on a more intense meaning, which can lead to the transition to intensifier by means of colloquial language.

\section{2. piekielnie/pekelne}

A closer look at the Polish lexical unit piekielnie and its analogous Slovak pekelne may help to answer the question in which contexts they (can) function as intensifiers. The lexeme piekielnie carries negative connotations because of its origin, namely hell as a place of suffering, purgatory and torment. Polish dictionaries give colloquial meanings as follows: 'coś ma daną cechę w tak dużym stopniu, że zwraca to uwagę mówiącego' (WSJP), and equate with 'bardzo' (SJP), 'bardzo, ogromnie, niezwykle (pod względem intensywności)’ (SDor), which are extended from its original sense:

(28) Wykręcona do tyłu ręka zaczęła piekielnie boleć i aby uniknąć bólu, grzecznie datem się połozyć na trawie.

(29) Jest nie tylko piekielnie inteligentny, ale i niezwykle charyzmatyczny i przebiegly jak lis.

(30) Dzięki nim nie traciłam wiary w siebie. A to dla każdego aktora jest piekielnie ważne.

(31) Przez dtugi czas uważano, że znalazt się w światowej czołówce tylko dlatego, że potrafi piekielnie mocno serwować.

(32) Uszliśmy dopiero nie więcej niż trzydzieści kilometrów. A to mało. To piekielnie mato. 
Analogically in Slovak, pekelne is derived from adjective pekelný $<$ peklo "súčasný význam vznikol po prijatí krest’anstva - akiste podl'a predstavy o hriešnikoch, ktorí po smrti trpia za svoje hriechy v horúcej smole" (SESS, p. 431), but in contemporary language its meaning is also spread to "vel'mi vel'ký, vel'mi intenzívny'. In contemporary Slovak it functions more often than not as synonymous to 'vel'mi' as in (33) - (36):

(33) Si rozumné dievča a pekelne dobrá pracovnička. Dostaneš takú prácu, akú chceš.

(34) A tiež viem že je 225 librový futbalový hráč v Iowe, ktorýje pekelne št'astný, že si sa odstahoval.

(35) Violet Youngová, pekelne krásna mladá hviezdička.

(36) To musel byt pekelne zaujímavý rozhovor.

Both, in Polish and Slovak, the original meaning piekielnie/pekelne was negative, connected with fear and superhuman abilities, which might have suggested the negative connotation of the whole expression. However, if we use the aforementioned lexeme as an intensifier, the superior, intensifying value will not be exposed to individual elements, but to the meaning of the whole expression (Moćko, 2012, pp. 45 $-46)$ :

(37) Jest to człowiek piekielnie odważny.

(38) Jesteśmy piekielnie bogatym krajem, trwonimy spadek po tylu talentach.

(39) Przyznaja, że jest szarmanckim, sympatycznym, rozmownym i piekielnie inteligentnym czlowiekiem.

(40) Vyzeráš v tom pekelne dobre, kámo. Sako s dvoma gombíkmi.

(41) Kde je ten pekelne št'astný chlapík?

(42) Je to rozdiel, ktorý za taký štandardný mesiac môže urobit' až $€ 1.500$ navyše a to už pekelne zaujímavá čiastka pre hocikoho.

In contexts (37) - (42), piekielnie/pekelne is used to strengthen the adjectives with a positive axiological component: Pl. odważny, bogaty, inteligentny, Sk. dobrý, štastný, zaujimavý by adding the intensifying component very, more than... The positive connotation of the adjective is emphasised by an intensifier and the whole expression is getting boosted.

On the other hand, as in (43) - (48), these adverbial intensifiers may appear with the adjectives with a negative component: Pl. przykry, brzydki, glupi, Sk. deštruktívny, nebezpečný, škaredý:

(43) Zwracaja się do tego umystu po pomoc i radę. Sprawa jest piekielnie przykra, zawita, niejasna, niewyttumaczona i przypomina takie oszalate kaprysy przyrody jak piorun z jasnego nieba.

(44) Za składem węgla byt dom, o którym już pisałam, a potem krzywo postawiony, piekielnie brzydki dom sklepikarza Cabańskiego. 
(45) - Piekielnie glupi! - zgniewat się niespodzianie pan Mudrowicz. - I ty też, jeśli myślisz tak samo.

(46) Je to pekelne deštruktívne, to čo sa stalo, nemyslite, šéfe?

(47) Pozri, ten chlap je na hrane a to to robi pekelne nebezpečným.

(48) Ona je geniálna a ty si idiot. Ona je... nuž, dost' sa zmenila na atraktívnu babu - na humusáčku - a ty si pekelne škaredý.

The usage of an intensifier makes these statements stronger in their negative meanings, i.e. piekielnie brzydki or pekelne škaredý means 'more than ugly', 'very ugly' - in which the negative connotation of the adjective is also emphasised.

The intensifier piekielnie/pekelne can also boost the adjectives with a neutral axiological component, as shown in (49) - (57):

(49) Musimy iść do Yat. Uszliśmy dopiero nie więcej niż trzydzieści kilometrów. A to mało. To piekielnie malo. Więc wstawaj, styszysz? Wstawaj!

(50) Obydwa gole dla gości to zastuga Le Tissiera - najpierw strzelit piekielnie silnie i piłka ocierając się o Elkinsa wpadła do siatki; potem idealnie obstużyt Moore'a.

(51) Wczoraj na tym przeklętym placu było piekielnie goraco. Poszedłem do lodziarni, zamówitem porcję lodów.

(52) I znów czeka ich kolejny, piekielnie nudny dzień i kolejna noc, która za krótka jest na sen...

(53) Ked' budete mat' plné zuby padajúceho snehu, hra vás prenesie do pekelne horúcej púšte Afriky.

(54) Bohužial', od teórie k praxi je cesta pekelne dlhá.

(55) Corvette je nielen názov lode, ale aj fascinujúco emotivneho a pekelne rýchleho auta, ktoré vám opantá všetky zmysly.

(56) Sú dni, ked' napokon zaspávate pekelne unavení, ale štastní. My sme prežili uplynulý týždeñ presne takéto dni.

(57) Prezeral som si ich, a sú pekelne drahé.

As shown above, the intensifiers' role is to boost the meaning of the adjective.

Another important aspect that should be underlined in the context of intensification is the occurrence of piekielnie/pekelne as intensifiers with various parts of speech. In examples (58) - (63), the verbs and participles get an intensified meaning of 'very' by piekielnie/pekelne:

(58) To bolało. To piekielnie bolato, tym bardziej, że Ted, nie bez racji, wyczuwat za ta odmowa jeszcze inny powód, coś, o czym nie chciała nawet napomknać.

(59) Model siedział piekielnie znudzony $w$ trzcigodnym fotelu, Apelles zaś, ćmiąc fajeczkę, która mu wolno było zatruwać powietrze jedynie w przyzwoitej odległości od siedzib ludzkich, ustawit sztalugi na trawniku i przedziwnewyprawial awantury.

(60) Rozpútal armádu. Pekelne dúfam, že ste pripravení, chlapci, pretože vojna sa len začala. Tak teda... máme prácu. 
(61) Mal som malú nehodu, vyhodil som si koleno a teraz to pekelne bolí.

(62) Pekelne unudená a osamelá, tam by to bolo.

The lexical units piekielnie/pekelne also appear as intensifiers in combination with other/subsequent adverbs, as in the statements (63) - (72). They intensify adverbs: Pl. mocno, brudno, dobrze, mało, Sk. d'aleko, vel'a, zle, rýchlo: being nongradable units they open positions for gradable ones.

(63) Przez długi czas uważano, że znalazł się w światowej czołówce tylko dlatego, że potrafi piekielnie mocno serwować.

(64) Dlaczego prawie wszędzie w miejscach publicznych jest tak piekielnie brudno? Za komuny mówiło się, że to ustrój winien. A teraz? Jakie jest usprawiedliwienie?

(65) Nie znat stylów walki z szermierczych traktatów. Będzie walczył jak chtopak z miasta. Czyli piekielnie dobrze, bez żadnych zasad. Skutecznie.

(66) - Bieda w tym, że jest nas tak piekielnie malo - smętnie kiwat głowa Zautdin Imagożew, wpatrując się w zakurzona ścienna mape.

(67) Aj ked' Newport je pekelne d'aleko od Brea. Ty si z Brea? Kde si chodil na základnú?

(68) Bude tam pekelne vel'a Walkerovcov. Už som vel'ký, viem sa o seba postarat'.

(69) Vyzeráte pekelne zle.

(70) Kiteboarding je pekelne rýchlo rozvijajúci sa šport, ktorý spája windsurfing $s$,,doskovými “ športmi ako surfing, snoubording či skejtbording.

\section{3. diabelnie (diabelsko)/diabolsky}

An analogous analysis can be made for the adjectival adverb diabelsko/ diabolsky, which means in Polish: 1. 'mający cechy przypisywane diabłu' ('having attributes associated with the devil; satanic'); 2. 'przebiegły, niebezpieczny; szatański' ('clever, devious, dangerous'); 3. (metaphorical meaning): 'ogromny, niesamowity; diabelny, piekielny' ('huge, amazing; devilish, hellish'). WSJP notices a positive meaning, confirmed by (71) - (73): coś ma daną cechę w tak dużym stopniu, że zwraca to uwagę mówiącego i jest przez niego uważane za niezwykłe i pozytywne ('something has a feature to such an extent that it gets the speaker's attention and is regarded as unusual and positive'):

(71) Dziennikarze przyrównuja naszą szkótkę do szlifierni diamentów i myślę, że jest to diabelsko dobre porównanie - mówi Adrianse.

(72) - Ale nie martw się-pocieszyłam go, czując się diabelsko dobrze. - I tobie się kiedyś powiedzie.

(73) Emanuje piekielna energia i jest diabelsko inteligentny.

There is in Polish another synonymous adverb diabelnie, which is described as a colloquial synonym to 'bardzo' (very) and in SJP equates with intensywny, niesamowity. WSJP also points the colloquial, intensive usage of diabelnie: 'w takim 
stopniu, który mówiący uznaje za bardzo duży i nietypowy w danej sytuacji, tak że trudno się spodziewać, że to, o czym mowa, będzie miało tę cechę właśnie w takim stopniu ("to such extent that the speaker considers it to be very large and unusual in a given situation, so that it is difficult to expect that what we are talking about will have this feature in that degree'):

(74) Kluczowe dla całej książi jest pierwsze zdanie: „Diabelnie trudno kłamać, kiedy człowiek nie zna prawdy."

(75) I wszystkim się to diabelnie spodobało.

(76) Widzi pan, po tej maturze zaczęła mnie dręczyć myśl, że przyzwoitość diabelnie dużo kosztuje.

As far as the Slovak adverb diabolsky is concerned, it is noted in SSSJ as: 1. príznačne pre diabla, podobne ako diabol, ako stelesnenie zla 'characteristic of the devil, as a devil, the incarnation of evil'; 2. (expressive meaning): poukazujúc na prehnane vel'kú mieru niečoho (schopností, vlastností), vel'mi ('indicating the exaggerated degree of something (features, characteristics)', very'), i.e. (77) - (80):

(77) A toto je príbeh o človeku, ktorý bol diabolsky šikovný?

(78) Chod' a bud' diabolsky šarmantný.

(79) Som diabolsky vyčerpaný. Potrebujem sa vrátit’ do školy a trochu oddýchnut'.

(80) Parfum dostanete v elegantnom $50 \mathrm{ml}$ balení. Diabolsky dobrá akcia za menej!

(81) Avšak vymyslel to diabolsky dokonale.

(82) Ich nezaujíma že na jednej strane sa ti strkajú do zadku reklamami ponúkaných výhod a na druhej strane človeka ožobračia... diabolsky dobre to majú premyslené...

(83) Po dlhšom čase sme sa stretli s Cigánskymi Diablami na Vianočnom turné $v$ Košiciach. Koncert bol, ako zvyčajne fantastický. Diabli hrali diabolsky skvele. Písat' o ich hudbe je vel'mi obtiažne, nakol'ko slová nemôžu v žiadnom pripade vyjadrit'...

The Polish and Slovak aforementioned corpora examples show a very wide range of collocating adjectives and adverbs. A closer look at the above cases (84) (89) allows us to consider the usage of these intensifiers as adverbs with a primary meaning connected with the devil and evil:

(84) Prawdziwie diabelsko kusit zebranych tego wieczoru Andrzej Starmach, pod młotek którego trafily prawdziwe rarytasy - 200 dzieł największych wspótczesnych artystów, wśród których m.in. obrazy Zdzisława Beksińskiego, Jana Młodożeńca, Jerzego Nowosielskiego, Jarosława Modzelewskiego, Teresy Pagowskiej.

(85) Jonathan wybuchnąt śmiechem, a Tomaszek, chichoczac diabelsko, wskoczył znów pod kołdrę. 
(86) Nadchodzi wieczór, mięśnie mi sztywnieją, staję się nieobliczalny i dziwnie nakręcony, drobiazg sprawia że wpadam w szat złości, wszystko niszcza dookoła, nic do mnie nie dociera, trzęsę się, diabelsko chce mi się zrobić coś zlego $(\ldots)$

(87) „,Takže ty takto “ diabolsky sa uškrnul.

(88) Povedal Gerard a znova sa diabolsky usmial.

(89) Ako som odomykal dvere, nevšimol som si, že Ikyzuki sa za mojim chrztom diabolsky smeje, ako keby som padol do nejakej jeho pasti.

The above presented illustrations have shown the different collocations of lexical units potwornie, piekielnie, diabelsko, príšerne, pekelne, diabolsky, which were considered as intensifiers. They confirm that intensifiers diffuse first, and only after the diffusion to collocating with a large number of adjectives the numbers of usage surge. These adverbs, originally negatively valued occur with positively, as well as negatively evaluated adjectives and adverbs. If such adverbs have gradually lost their negative evaluation and occur with positively evaluated adjectives (inteligentný, dobrý, zaujimavý, štastný), this can be taken as evidence for being further in the delexicalization process, because of the contradictory lexical meanings occurring as collocations. This seems a legitimate deduction as those adverbs must have lost most of their lexical meaning, because if they still had retained the lexical meaning, these combinations would sound utterly strange (Tagliamonte, 2008, pp. 375, 380).

\section{CONCLUSION}

Intensity, as a cognitive concept, refers to cognitive processes based on conscious or subconscious comparisons of everything we perceive (Batinić - Kresić - Pavić Pintarić, 2015, p. 6). It is also the difference between what the speaker wants to express and the standard language. Verification of this difference is the result of a subjective perception of reality by the speaker (Bałabaniak, 2013, p. 79). In Polish studies, intensifiers are perceived as:

- self-referential, contextual units, carrying the absolute dimension of a feature;

- subjective items characterized by a strong emotional and figurative character;

- non-gradable units, standing next to gradable lexemes; their primary position is the adjectival position; intensifiers do not enter into relationships with a noun or forms of a comparative, and as determinants of a progressive predicate, they do not refer directly to the object described by a progressive predicate;

- the items originating from a class of adverbs;

- the lexicalized unit: lexicalization starts from the erasing of the original meanings of lexemes through connectivity with semantically-related lexemes marked in the same or opposite manner.

To conclude, this study attempted to show that the usage of primarily negatively marked adverbs/intensifiers with lexemes marked both negatively and positively is 
acceptable. I have discussed the intensifying functions of lexical units descended from adverbs in a cross-linguistic Polish-Slovak perspective mainly due to the process of their delexicalization. Through frequency of use and over time, intensifiers tend to lose their intensifying force and the renewal process occurs. This process promotes other adverbs, be they newly created adverbs or already existing ones, to the rank of intensifiers (Bordet, 2017a). Bolinger stated that it is impossible to list all the intensifiers. The linguists' research shows that this is true (Bałabaniak distinguished bardzo, wysoce, wielce, cholernie, piekielnie, diabelnie, strasznie, straszliwie, potwornie, okropnie, ogromnie, szalenie), so it seems that the class of intensifiers may be an open class because some intensifying features also indicate isolated or ad hoc connections - the assessment of their possible lexicalization can be left open (Bałabaniak, 2013, p. 100). My analysis has shown that there are a number of aspects which can be taken into consideration while describing intensifiers. The previous studies on intensification in Polish have mainly dealt with grading and idioms as a measure of intensification. The review of the Slovak intensifying units confirms that intensification has not been studied in a comprehensive manner so far (apart from aforementioned Kralčák, 1992 and few studies by Hansmanová, 2005, 2010), so such a thesis may also be posed and examined in the Slovak language. Furthermore, crosslinguistic work is needed to explore whether they develop along the same lines as described in this paper. This could provide fruitful ground for future research in the intensification system of Slovak.

\section{References}

ATHANASIDOU, Angeliki: On the subjectivity of intensifiers. In. Language Sciences, 2007, Vol. 29, pp. $554-565$.

BAŁABANIAK, Dagmara - MITRENGA, Barbara: Polskie intensyfikatory w ujęciu historycznym. Katowice: Wydawnictwo Uniwersytetu Śląskiego 2015. 192 pp.

BAŁABANIAK, Dagmara: O użyciu wyrażeń przysłówkowych w pozycji intensyfikatora. In: Linguarum Silva, 2014, № 3, pp. 29 - 39.

BAŁABANIAK, Dagmara: Polskie intensyfikatory leksykalne na tle wyrażeń gradacyjnych. Opole: Uniwersytet Opolski 2013. 152 pp.

BATINIĆ, Mia - KRESIĆ, Marijana - PAVIĆ PINTARIĆ, Anita: The intensifying function of modal particles and modal elements in a cross-linguistic perspective. In: Rasprave. Časopis Instituta za hrvatski jezik i jezikoslovlje, 2015, Vol. 41 № 1, pp. 1 - 27.

BELTRAMA, Andrea: Intensification and Sociolinguistic Variation: A Corpus Study. In: Proceeding of the forty-first annual meeting of the Berkeley Linguistic Society. Eds. A. E. Jurgensen - H. Sande - S. Lamoureux - K. Baclawski - A. Zerbe. Berkeley: Berkeley Linguistics Society, 2015, pp. $15-30$.

BOLINGER, Dwight: Degree words. The Hague: Mouton 1972. 325 pp.

BORDET, Lucile: From vogue words to lexicalized intensifying words: the renewal and recycling of intensifiers in English. A case-study of very, really, so and totally. In: Lexis. 
Journal in English Lexicology. The expression of intensity, 2017a, № 10. Available at: http:// journals.openedition.org/lexis/1125

BORDET, Lucile: References. In: Lexis. Journal in English Lexicology. The expression of intensity, 2017b, № 10. Available at: https://journals.openedition.org/lexis/1141

DOROSZEWSKI, Witold (ed.): Słownik Języka Polskiego. Warszawa: PWN 1950 - 1969.

GREENBAUM, Sidney: Verb-Intensifier Collocations in English. An experimental approach. The Hague: Mouton 1970. 96 pp.

HANSMANOVÁ, Júlia: Intenzifikácia. In: Morfologické aspekty súčasnej slovenčiny. Ed. J. Dolník. Bratislava: Veda, vydavatel'stvo SAV 2010, pp. 401 - 448.

HANSMANOVÁ, Júlia: Kategoriálne formy intenzifikácie. In: Varia XII. Ed. V. Kováčová. Ružomberok - Bratislava: Katolícka univerzita v Ružomberku - Slovenská jazykovedná spoločnost’ pri SAV 2005, pp. 150 - 159.

HOPPER, Paul - TRAUGOTT, Elisabeth: Grammaticalization. Cambridge: Cambridge University Press 2003, 278 pp.

JAKUBCZAK, Ireneusz: Adjective intensifiers in English and Polish. In: Linguistica Silesiana, 1985, № 7, pp. 63 - 99.

JAKUBOWICZ, Martyna: Czym mogą być motywowane wykładniki intensywności? Na przykładzie różnojęzycznych odpowiedników polskiego bardzo. In: Wyrażenia funkcyjne w perspektywie diachronicznej, synchronicznej i porównawczej. Ed. K. Kleszczowa. Katowice: Wydawnictwo Uniwersytetu Śląskiego 2014, pp. 66 - 76.

JAROŠOVÁ, Alexandra - BUZÁSSYOVÁ, Klára (eds.): Slovník súčasného slovenského jazyka. A- G. [1. zv.]. Bratislava: Veda, vydavatel'stvo SAV 2006, 1134 pp.

KAČALA, Ján - PISÁRČIKOVÁ, Mária (eds.): Krátky slovník slovenského jazyka. Bratislava: Veda, vydavatel'stvo SAV 1997, 944 pp.

KOZIARA, Stanisław: „Strasznie, dokładnie“. In. Język Polski, 2003, z. 4/5, pp. 348 - 350.

KRALČÁK, Lubomír: Lexikálna intenzifikácia deja a vlastnosti. In: Varia I. Eds. M. Nábělková - M. Šimková. Bratislava: Slovenská jazykovedná spoločnost' pri SAV 1992, pp. 20 - 24.

KRÁLIK, Lubor: Stručný etymologický slovník slovenčiny. Bratislava: Veda, vydavatel'stvo SAV 2015, 704 pp.

LEBEDEVA, Irina - PAVLOVA, Lena: Intensifiers in modern English. In: Вестник МГЛУ, 2016. Выпуск 21 (760), pp. 43 - 56.

LEHMANN, Christian: New reflections of grammaticalization and lexicalization. In: New reflections of grammaticalization. Eds. I. Wischer - G. Diewald. Amsterdam/Philadelphia: John Benjamins Publishing Company 2002, pp.1 - 18.

LORENZ, Gunter: Really worthwhile or not really significant? A corpus-based approach to the delexicalization and grammaticalization of intensifiers in Modern English. In: New reflections of grammaticalization. Eds. I. Wischer - G. Diewald. Amsterdam/Philadelphia: John Benjamins Publishing Company 2002, pp. 143 - 161.

MISZ, Henryk: Opis grup syntaktycznych dzisiejszej polszczyzny pisanej. Bydgoszcz: Bydgoskie Towarzystwo Naukowe 1967. 149 pp.

MITRENGA, Barbara: Status jednostek typu sensacyjnie, prowokacyjnie i skandalicznie w polszczyźnie. Rozważania o nowych intensyfikatorach leksykalnych. In. Sensacja, prowokacja, skandal: o przekraczaniu norm kulturowych. Ed. G. Różańska. Pruszcz Gdański: Wydawnictwo Jasne; Słupsk: Akademia Pomorska 2016, pp. 225 - 242. 
MOĆKO, Natalia: “Anielsko cierpliwy i piekielnie inteligentny”: o intensyfikacji w profanum za pomocą sacrum. In. Linguarum Silva, 2012, № 1, pp. 37 - 54.

Narodowy Korpus Języka Polskiego. Available at: http://www.nkjp.uni.lodz.pl/

Omnia Slovaca Publica II. (17.10) 4,34 G. Bratislava: Univerzita Komenského, Katedra plurilingválnej a multikultúrnej komunikácie - Jazykovedný ústav L’udovíta Štúra SAV 2016. Available at: http://ucts.uniba.sk/aranea/index.html, aranea.juls.savba.sk

PARADIS, Carita: It's well weird. Degree modifiers of adjectives revisited: The nineties. In: Corpora galore: analyses and techniques in describing English. Ed. J. Kirk. Amsterdam Atlanta: Rodopi 2000, pp.147 - 160.

PARTINGTON, Alan: Corpus evidence of language change: The case of intensifiers. In: Text and technology: In honour of John Sinclair. Eds. M. Baker - G. Francis - E. Tognini-Bonelli. Amsterdam and Philadelphia: John Benjamins 1993, pp. 177 - 192.

PUZYNINA, Jadwiga: O pojęciu intensyfikacji. In: Roczniki Humanistyczne, 2001 2002, XLIX - L, № 6, pp. 321 - 327.

QUIRK, Randolph - GREENBAUM, Sidney - LEECH, Geoffrey - SVARTVIK, Jan: A comprehensive grammar of the English Language. London: Longman 1985, 1779 pp.

RECSKI, Leonardo: “...It's Really Ultimately Very Cruel...”: contrasting English intensifier collocations across EFL writing and academic spoken discourse. In: DELTA. Documentação de Estudos em Lingüística Teórica e Aplicada, 2004, Vol. 20, № 2, pp. 211 - 234.

REICHELD, Susan - DURHAM, Mercedes: Adjective intensification as a means of characterization: portraying in-group membership and Britishness in Buffy the Vampire Slayer. In: Journal of English Linguistics, 2017, Vol. 45, № 1. Available at: https://journals.sagepub. com/doi/abs/10.1177/0075424216669747

SZYMCZAK, Mieczysław (red.): Słownik Języka Polskiego PWN. Warszawa: Państwowe Wydawnictwo Naukowe 1978 - 1981.

ŠIKRA, Juraj: Sémantika slovenských prísloviek. Bratislava: VEDA, vydavatel'stvo SAV 1991. $212 \mathrm{pp}$.

STOFFEL, Cornelis: Intensives and Down-toners: A study in English adverbs. Heidelberg: Carl Winter's Universitätsbuchhandlung 1901. 161 pp.

TAGLIAMONTE, Sali: So different and pretty cool! Recycling intensifiers in Toronto, Canada. In: English Language and Linguistics, 2008, Vol. 12, № 2, pp. 361 - 394.

WĘGIEL, Maria: Jakie są ograniczenia łączliwości składniowej przysłówków? (Na przykładzie łączliwości leksemu bardzo). In: Studia gramatyczne, 1995, Vol. XI, pp. 107 - 112.

ŻMIGRODZKI, Piotr (zest.): Wielki słownik języka polskiego PAN. Wyd. drugie. Kraków: Instytut Języka Polskiego PAN 2015.

\author{
Abbreviations: \\ WSJP - Wielki Stownik Języka Polskiego. Available at: http://www.wsjp.pl/ \\ KSJ - Krátky slovnik slovenského jazyka. Available at: http://slovniky.juls.savba.sk/ \\ SESS - Stručný etymologický slovník slovenčiny \\ SDor - Stownik Języka Polskiego pod red. W. Doroszewskiego. Available at: https://sjp.pwn.pl/ \\ SJP - Stownik Języka Polskiego. Available at: https://sjp.pwn.pl/ \\ SSSJ - Slovník súčasného slovenského jazyka. Available at: http://slovniky.juls.savba.sk/
}

